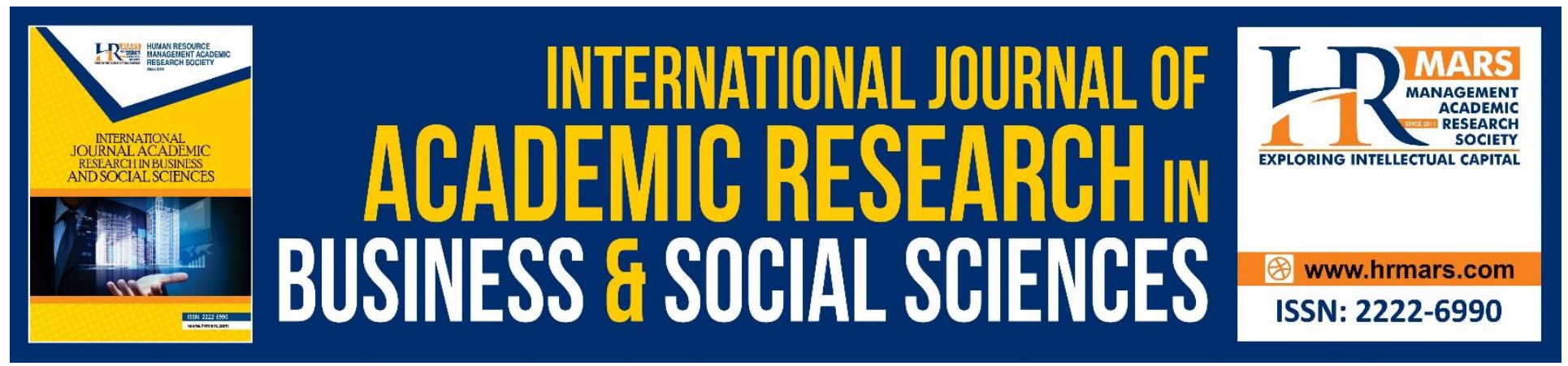

\title{
Employability Skills in Business Management Graduate and Role of Malaysian Vocational College
}

\section{Ramdzan Ali Saibon and Arasinah Kamis}

To Link this Article: http://dx.doi.org/10.6007/IJARBSS/v9-i2/5674

DOI: $10.6007 /$ IJARBSS/v9-i2/5674

Received: 09 Feb 2019, Revised: 26 Feb 2019, Accepted: 06 March 2019

Published Online: 18 March 2019

In-Text Citation: (Saibon \& Kamis, 2019)

To Cite this Article: Saibon, R. A., \& Kamis, A. (2019). Employability Skills in Business Management Graduate and Role of Malaysian Vocational College. International Journal of Academic Research in Business and Social Sciences, 9(2), 1175-1192.

Copyright: (C) 2019 The Author(s)

Published by Human Resource Management Academic Research Society (www.hrmars.com) This article is published under the Creative Commons Attribution (CC BY 4.0) license. Anyone may reproduce, distribute, translate and create derivative works of this article (for both commercial and non-commercial purposes), subject to full attribution to the original publication and authors. The full terms of this license may be seen at: $\underline{\text { http://creativecommons.org/licences/by/4.0/legalcode }}$

Vol. 9, No. 2, 2019, Pg. 1175 - 1192

Full Terms \& Conditions of access and use can be found at http://hrmars.com/index.php/pages/detail/publication-ethics 


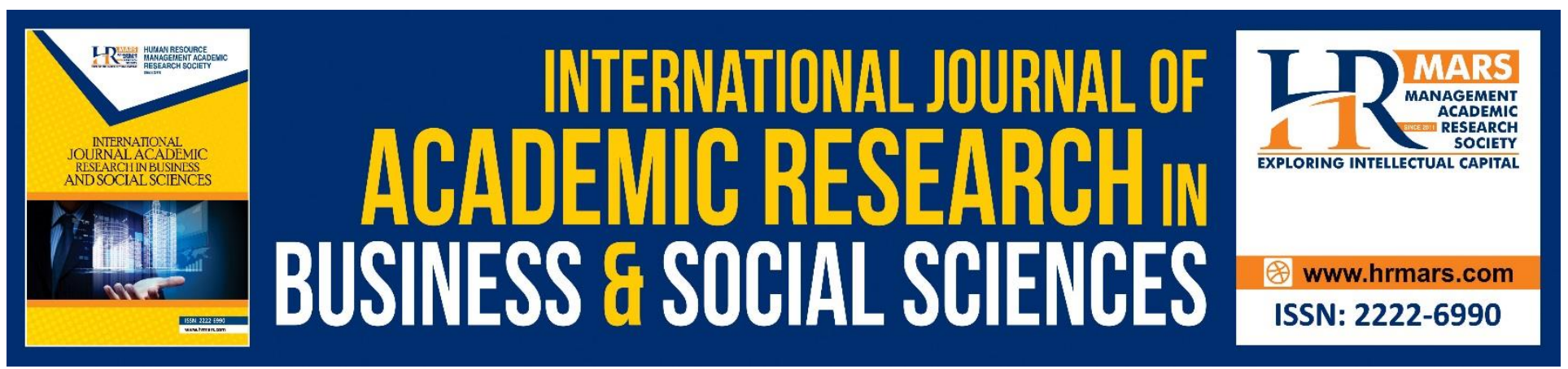

\title{
Employability Skills in Business Management Graduate and Role of Malaysian Vocational College
}

\author{
Ramdzan Ali Saibon and Arasinah Kamis \\ Faculty of Technical and Vocational, Sultan Idris Education University, 35900 Tanjung Malim, Perak, \\ Malaysia
}

\begin{abstract}
Employability skills among graduates are a key requirement for them to get jobs in the labor market. However, not all graduates have the employability skills required by employers. Therefore, this article aims to examine the importance of employability skills that must be mastered by Business Management graduates in vocational colleges (KVs). Human Capital Theory, Self-Concept Theory of Career Development and Skills Relationship Model has been linked to this article. Employability skills that must be mastered by Business Management graduates are the skills of analysis and problem solving, communication, information technology application, leadership and management, teamwork and interpersonal and entrepreneurial. The need for employability skills is a priority for employers as well as technical skills. It is also a key criterion in determining the employability and marketability of graduates in the labor market. This article also recommends that KVs take the initiative to inculcate employability skills among Business Management graduates, so they are more prepared and equipped with the skills required by employers and thus have the opportunity to gain employment in the labor market.
\end{abstract}

Keywords: Employability Skills, Employability, Marketability, Business Management Graduation, Vocational College.

\section{Introduction}

Employability skills are the key skills required in each self-employed especially KV Business Management graduates. This is to ensure that they can get jobs in the labor market as well as create their own job opportunities. Employability skills are the skills needed not only to gain employment, but to progress in the enterprise to achieve the potential of a person who can contribute to the organization's success (Aida, Norailis, \& Rozaini, 2015). It is also the ability of a person to get a job appropriate to his qualifications, relevant in the labor market, and be able to make a transition between his or her job in the same organization or capable of finding new jobs in the labor market (Mohamad, Rafikul, \& Hazilah, 2014). Employability skills can be regarded as an aspect of the overall job competence that graduates need to meet the needs and requirements of the industry employers 
to position themselves in the labor market and enable them to become skilled and capable employees in the field of work (Mohd, Isma, Fathin, \& Norhayati, 2016). Therefore, employability skills among graduates can be regarded as a measure of the employability and marketability of graduates after graduation. In view of the fact that the current job market situation requires not only the employees with the skills in the academic field but also requires productive and knowledgeable workers (Mohd et al., 2016).

The unemployment rate in Malaysia is considered to be alarming when it records a value of 3 percent almost every year. In August 2017, the unemployment rate posted a 3.4 per cent, down 0.1 percentage point compared to the previous month, while over the years, the unemployment rate fell by 0.1 percentage points compared to August 2016 (Department of Statistics Malaysia, 2017). Although it showed a slight decrease of 0.1 percentage point compared to the previous month and year, however, it showed an increase compared to 2015 and previous years. This situation illustrates that the trend of unemployment rate in Malaysia is consistent at a relatively high rate for each year. This explains that the issue of unemployment in Malaysia is a prolonged issue and is not a temporary issue. The unemployment phenomenon and the difficulty in obtaining jobs among graduates of tertiary institutions are at a very worrying level (Chun \& Chien, 2015; Dian, Umi, Hana, \& Mohd, 2015; Kee, Hill, Fernandez \& Yin, 2016; Norliana, Chang, Mat \& Rahman 2016; Suhaili, 2015; Nordin, \& Ridzwan, 2015). This is a phenomenon that involves various levels and programs of study, especially the KV Business Management Program. The studies conducted by Atif Aziz and Faizuniah (2017) found that Business Management graduates ranked highest in the list of youth unemployed in Malaysia. This finding will also complicate the efforts of the KV to achieve their goal of targeting 70 percent of graduates for each intake to get jobs, 10 percent to become entrepreneurs and 20 percent to continue their studies.

This unemployment phenomenon is caused by several factors. Among these factors is the lack of employability skills among graduates themselves. In addition, the inequality between the skills required by the employer of the industry and the skills possessed by the graduates is also one of the factors that contributed to this unemployment phenomenon. There is an inequality between graduates produced by the Institute of Public Skills Training in Malaysia and the competent work force required by industry employers. The employers have also tried to state some of the employability skills they want from graduates (Bishanani, Sharifah, \& Norlidah, 2016). Even employers also emphasize the importance of employability skills among graduates to ensure that they become highly skilled workers in their work (Bishanani et al., 2016).

\section{Employability Skills}

There are many studies that examine the employability skills. This is because the issue of employability skills among graduates is an important issue that is often discussed over the years. Many recent studies have discussed employability skills involving various parties including industry employers, tertiary institutions and graduates themselves (Jackson, 2016a, 2016b; Kee-Cheok Cheong et al., 2016; Noor Lela Ahmad \& Suraini Mohd Rhouse, 2016; O'Leary, 2017; Williams, Dodd, Steele, \& Randall, 2016; Windes \& Hamilton, 2017; Zaliza \& Arasinah, 2017). The study conducted by 
Zaliza and Arasinah (2017) found that the mastery of the technical skills and employability skills of each grader is an important criterion for enabling them to obtain employment in the current labor market. In fact, the difference between the skills needed in a job with the skills possessed by graduates is a real concern to top management and human resources who want competent employees (Aida et al., 2015).

Different jobs require different skill mastery. Similarly, employability skills where not all fields of work require the same control of the same employability skills. Most of the work now requires not only knowledge in certain areas, but also emphasizes on employability skills. Pramela, Kamisah, Subahan, and Zanaton (2014) found it difficult and challenging for employers to have graduates able to communicate well, especially in English. They also consider the decline in English fluency as the main weakness among graduates today. Employers are deeply concerned with the mastery of English as it helps to enhance the potential of graduates' career and is an invaluable asset to any global organization (Pramela et al., 2014).

Meanwhile, Zafir, Ishak Yussof, and Abd (2015) have shown that the performance of graduates in terms of ethics and values, thinking skills, leadership, decision-making and problem solving are considered to be quite a skill gap by employers. The study, conducted by Suhaili (2015), emphasized both technical skills and employability skills. His research also found that graduates issued by tertiary institutions did not have technical skills related to some aspects required by industry employers. In fact, this study also found that the employers strongly need employees with the employability skill (Suhaili, 2015). Table 1 below is some of the last studies related to this article.

Table 1. Literature Related to Employability Skills

\begin{tabular}{|c|c|c|c|c|}
\hline Researcher & Research topic & Research Objectives & Employability Skills & $\begin{array}{l}\text { Research } \\
\text { Results }\end{array}$ \\
\hline $\begin{array}{l}\text { Alshare } \\
\text { (2018) }\end{array}$ & $\begin{array}{l}\text { A Gap Analysis } \\
\text { Of Business } \\
\text { Students' Skills } \\
\text { In The } 21 \text { St } \\
\text { Century: A Case } \\
\text { Study Of Qatar }\end{array}$ & $\begin{array}{l}\text { Explore whether } \\
\text { there is a gap } \\
\text { between the skills / } \\
\text { competencies of } \\
\text { business students } \\
\text { provided by business } \\
\text { colleges and current } \\
\text { job market needs. }\end{array}$ & $\begin{array}{l}\text { Critical thinking / } \\
\text { Problem solving, } \\
\text { creativity/innovation, } \\
\text { collaboration / } \\
\text { Teamwork, written), } \\
\text { communications (oral } \\
\text { \& professionalism, } \\
\text { leadership, } \\
\text { information } \\
\text { technology, } \\
\text { interpersonal skills, } \\
\text { technical skills, } \\
\text { flexibility/adaptability, } \\
\text { multicultural } \\
\text { awareness, work ethic, }\end{array}$ & $\begin{array}{l}\text { The findings } \\
\text { show that there } \\
\text { is a gap } \\
\text { between the } \\
\text { skills } \\
\text { competence of } \\
\text { business } \\
\text { students with } \\
\text { the skills / } \\
\text { competencies } \\
\text { required by } \\
\text { employers. }\end{array}$ \\
\hline
\end{tabular}




\begin{tabular}{|c|c|c|c|c|}
\hline & & & $\begin{array}{l}\text { planning and } \\
\text { organizing, } \\
\text { voluntarism, analytic } \\
\text { thinking, social } \\
\text { responsibility, dealing } \\
\text { with real world } \\
\text { problems, knowledge, } \\
\text { creativity/innovation, } \\
\text { global business and } \\
\text { decision making. }\end{array}$ & \\
\hline $\begin{array}{l}\text { Nur Farha } \\
\text { Hassan, } \\
\text { Saifullizam } \\
\text { Puteh, and } \\
\text { Amanina } \\
\text { Muhamad } \\
\text { Sanusi } \\
\text { (2018) }\end{array}$ & $\begin{array}{l}\text { Elements of } \\
\text { Technology } \\
\text { Enabled/Enhan } \\
\text { ced Active } \\
\text { Learning (TEAL) } \\
\text { to Enhance } \\
\text { Quality and } \\
\text { Employability of } \\
\text { Bachelor's } \\
\text { Students }\end{array}$ & $\begin{array}{l}\text { Determines the } \\
\text { element of } \\
\text { Technology Enabled } \\
\text { / Enhanced Active } \\
\text { Learning (TEAL). }\end{array}$ & $\begin{array}{l}\text { Telecommunication } \\
\text { Media and } \\
\text { Computer, decision } \\
\text { making and action, } \\
\text { critical thinking and } \\
\text { problem solving. }\end{array}$ & $\begin{array}{l}\text { The findings } \\
\text { show that this } \\
\text { TEAL element } \\
\text { will help } \\
\text { institutions to } \\
\text { promote } \\
\text { students to } \\
\text { engage in active } \\
\text { learning. }\end{array}$ \\
\hline $\begin{array}{l}\text { Zaliza } \\
\text { Hanapi and } \\
\text { Arasinah } \\
\text { Kamis } \\
\text { (2017) }\end{array}$ & $\begin{array}{l}\text { Comparative } \\
\text { analysis } \\
\text { between } \\
\text { industry, } \\
\text { lecturers and } \\
\text { graduates on } \\
\text { the importance } \\
\text { of technical } \\
\text { skills and } \\
\text { employability } \\
\text { skills that must } \\
\text { be mastered by } \\
\text { electrical } \\
\text { graduates in } \\
\text { community } \\
\text { colleges. }\end{array}$ & $\begin{array}{l}\text { Review comparative } \\
\text { perceptions on the } \\
\text { importance of the } \\
\text { elements of } \\
\text { technical skills and } \\
\text { employability skills. }\end{array}$ & $\begin{array}{l}\text { Information } \\
\text { management skills, } \\
\text { self-management } \\
\text { skills, ethical and } \\
\text { moral skills, } \\
\text { entrepreneurial skills, } \\
\text { communication skills, } \\
\text { creative thinking and } \\
\text { critical thinking skills, } \\
\text { teamwork and } \\
\text { teamwork and } \\
\text { leadership skills. }\end{array}$ & $\begin{array}{l}\text { There is a } \\
\text { significant } \\
\text { difference in } \\
\text { the perception } \\
\text { of the } \\
\text { importance of } \\
\text { information } \\
\text { management } \\
\text { skills, self- } \\
\text { management } \\
\text { skills, ethical } \\
\text { and moral skills } \\
\text { as well as } \\
\text { entrepreneurial } \\
\text { skills between } \\
\text { employers, } \\
\text { graduates and } \\
\text { Community } \\
\text { College } \\
\text { lecturers. } \\
\text { However, } \\
\text { instead }\end{array}$ \\
\hline
\end{tabular}




\begin{tabular}{|c|c|c|c|c|}
\hline & & & & $\begin{array}{l}\text { communication } \\
\text { skills, creative } \\
\text { thinking and } \\
\text { critical thinking } \\
\text { skills, teamwork } \\
\text { and and } \\
\text { collaborative } \\
\text { skills a leadership skills. }\end{array}$ \\
\hline $\begin{array}{l}\text { Windes and } \\
\text { Hamilton } \\
\text { (2017) }\end{array}$ & $\begin{array}{l}\text { Preparing } \\
\text { Business } \\
\text { Students for } \\
\text { Participation in } \\
\text { God 's Creative } \\
\text { and } \\
\text { Redemptive } \\
\text { Purpose for the } \\
\text { World } \\
\text { Preparing } \\
\text { Business } \\
\text { Students for } \\
\text { Participation in } \\
\text { God' s Creative } \\
\text { and } \\
\text { Redemptive } \\
\text { Purpose for the } \\
\text { World. }\end{array}$ & $\begin{array}{l}\text { Combine business } \\
\text { education with } \\
\text { vocational } \\
\text { education, form the } \\
\text { curriculum and } \\
\text { evaluate its } \\
\text { effectiveness. }\end{array}$ & $\begin{array}{l}\text { Faithful in life, ethics, } \\
\text { understanding, } \\
\text { effective in teams, } \\
\text { critical in thinking, } \\
\text { innovative and } \\
\text { creative, professional } \\
\text { and technical } \\
\text { excellence in their } \\
\text { field of study. }\end{array}$ & $\begin{array}{l}\text { The results } \\
\text { obtained from } \\
\text { the training } \\
\text { supervisor are } \\
\text { in line with the } \\
\text { self-assessment } \\
\text { of the skills } \\
\text { students. }\end{array}$ \\
\hline $\begin{array}{l}\text { Bishanani } \\
\text { Omar et al. } \\
\text { (2016) }\end{array}$ & $\begin{array}{l}\text { Employability } \\
\text { Skills: Issues of } \\
\text { Vocational } \\
\text { College } \\
\text { Business } \\
\text { Management } \\
\text { Graduates. }\end{array}$ & $\begin{array}{l}\text { Discuss issues of } \\
\text { employment skills } \\
\text { among Business } \\
\text { Management } \\
\text { graduates in the KV. }\end{array}$ & $\begin{array}{l}\text { Employability Skills } \\
\text { There are various } \\
\text { interpretations of this } \\
\text { skill based on the field } \\
\text { involved. }\end{array}$ & $\begin{array}{l}\text { Employability } \\
\text { skills required } \\
\text { by students to } \\
\text { meet different } \\
\text { job } \\
\text { requirements. }\end{array}$ \\
\hline $\begin{array}{l}\text { Jackson } \\
\text { (2016) }\end{array}$ & $\begin{array}{l}\text { Modeling } \\
\text { graduate skill } \\
\text { transfer from } \\
\text { university to the } \\
\text { workplace. }\end{array}$ & $\begin{array}{l}\text { Expanding and } \\
\text { testing the model of } \\
\text { master's proficiency } \\
\text { in job skills. }\end{array}$ & $\begin{array}{l}\text { Working with others, } \\
\text { Communicating, Self- } \\
\text { awareness, Critical } \\
\text { thinking, Analyzing } \\
\text { data and using } \\
\text { technology, } \\
\text { Troubleshooting, }\end{array}$ & $\begin{array}{l}\text { The results } \\
\text { suggest that } \\
\text { various factors } \\
\text { influence the } \\
\text { efficiency of job } \\
\text { skills. }\end{array}$ \\
\hline
\end{tabular}




\begin{tabular}{|c|c|c|c|c|}
\hline & & & $\begin{array}{l}\text { Developing initiatives } \\
\text { and enterprises, Self- } \\
\text { management, Social } \\
\text { responsibility and } \\
\text { accountability, } \\
\text { developing } \\
\text { professionalism. }\end{array}$ & \\
\hline $\begin{array}{l}\text { Jackson } \\
\text { (2016b) }\end{array}$ & $\begin{array}{l}\text { Re- } \\
\text { conceptualising } \\
\text { graduate } \\
\text { employability: } \\
\text { the importance } \\
\text { of pre- } \\
\text { professional } \\
\text { identity. }\end{array}$ & $\begin{array}{l}\text { Redefine graduates' } \\
\text { employment by } \\
\text { incorporating pre- } \\
\text { professional identity } \\
\text { creation. }\end{array}$ & $\begin{array}{l}\text { Communication, } \\
\text { teamwork, self- } \\
\text { management and } \\
\text { critical thinking. }\end{array}$ & $\begin{array}{l}\text { Establishment } \\
\text { of Pre- } \\
\text { professional } \\
\text { Identity (PPI) } \\
\text { will benefit } \\
\text { graduates' } \\
\text { understanding } \\
\text { and effort for } \\
\text { improvement. }\end{array}$ \\
\hline $\begin{array}{l}\text { Noor Lela } \\
\text { Ahmad and } \\
\text { Suraini } \\
\text { Mohd } \\
\text { Rhouse } \\
\text { (2016) }\end{array}$ & $\begin{array}{l}\text { Professional } \\
\text { Skills Graduates } \\
\text { Accounting: } \\
\text { Among } \\
\text { Employers } \\
\text { Expectations } \\
\text { and Student } \\
\text { Needs in the } \\
\text { Accounting } \\
\text { Curriculum. }\end{array}$ & $\begin{array}{l}\text { Explore the } \\
\text { professional skills } \\
\text { required by the } \\
\text { career environment } \\
\text { based on the } \\
\text { perspective of the } \\
\text { employers industry } \\
\text { and final year of the } \\
\text { degree of } \\
\text { accounting. }\end{array}$ & $\begin{array}{l}\text { Technical skills } \\
\text { (accounting, finance } \\
\text { and taxation), } \\
\text { management skills, } \\
\text { information } \\
\text { technology skills, } \\
\text { intellectual skills, } \\
\text { interpersonal skills } \\
\text { and personal skills. }\end{array}$ & $\begin{array}{l}\text { There is a gap } \\
\text { between the } \\
\text { needs of the } \\
\text { students and } \\
\text { the } \\
\text { expectations of } \\
\text { employers on } \\
\text { professional } \\
\text { skills. }\end{array}$ \\
\hline $\begin{array}{l}\text { Kee-Cheok } \\
\text { Cheong et } \\
\text { al. (2016) }\end{array}$ & $\begin{array}{l}\text { Employing the } \\
\text { 'unemployable': } \\
\text { employer } \\
\text { perceptions of } \\
\text { Malaysian } \\
\text { graduates. }\end{array}$ & $\begin{array}{l}\text { Reporting on the } \\
\text { perception } \\
\text { Malaysian } \\
\text { employers } \\
\text { graduates of the } \\
\text { country. }\end{array}$ & $\begin{array}{l}\text { English language } \\
\text { proficiency, } \\
\text { communication skills, } \\
\text { analytical skills, and } \\
\text { critical thinking. }\end{array}$ & $\begin{array}{l}\text { Employers find } \\
\text { that graduates } \\
\text { can not be } \\
\text { admired and } \\
\text { marketability is } \\
\text { less dependent } \\
\text { on core skills } \\
\text { than } \\
\text { employability } \\
\text { skills and } \\
\text { intrinsic a } \\
\text { personality and } \\
\text { attitude } \\
\text { towards } \\
\text { graduates. }\end{array}$ \\
\hline
\end{tabular}


INTERNATIONAL JOURNAL OF ACADEMIC RESEARCH IN BUSINESS AND SOCIAL SCIENCES

Vol. 9, No. 2, Feb, 2019, E-ISSN: 222 2-6990 @ 2019 HRMARS

\begin{tabular}{|c|c|c|c|c|}
\hline $\begin{array}{l}\text { Mane and } \\
\text { Miravet } \\
(2016)\end{array}$ & $\begin{array}{l}\text { Using the job } \\
\text { requirements } \\
\text { approach and } \\
\text { matched } \\
\text { employer- } \\
\text { employee data } \\
\text { to investigate } \\
\text { the content of } \\
\text { individuals' } \\
\text { human capital. }\end{array}$ & $\begin{array}{l}\text { Prove that returns to } \\
\text { employability skills } \\
\text { vary depending on } \\
\text { the position of the } \\
\text { employee at the } \\
\text { firm. }\end{array}$ & $\begin{array}{l}\text { Problem solving, client } \\
\text { communica tion, high- } \\
\text { level communication, } \\
\text { planning skills, } \\
\text { horizontal } \\
\text { communication, } \\
\text { numeracy skills, } \\
\text { technical knowledge } \\
\text { and literacy skills. }\end{array}$ & $\begin{array}{l}\text { Employability } \\
\text { skills bring } \\
\text { positive returns } \\
\text { and are not } \\
\text { neglected by } \\
\text { any job. }\end{array}$ \\
\hline $\begin{array}{l}\text { Mohd } \\
\text { Hazwan } \\
\text { Mohd Puad } \\
\text { (2015) }\end{array}$ & $\begin{array}{l}\text { The Role Of } \\
\text { Employability } \\
\text { Skills Training } \\
\text { Programs In The } \\
\text { Workforce Of } \\
\text { Malaysia. }\end{array}$ & $\begin{array}{l}\text { Reviewed the } \\
\text { perceptions of } \\
\text { educators, } \\
\text { employers, and new } \\
\text { graduates on the } \\
\text { role of skills training } \\
\text { programs } \\
\text { Malaysia's } \\
\text { workforce. }\end{array}$ & $\begin{array}{l}\text { Discipline and } \\
\text { integrity, } \\
\text { interpersonal skills, } \\
\text { and professionalism, } \\
\text { creativity and } \\
\text { innovation, teamwork, } \\
\text { lifelong learning, the } \\
\text { ability to apply } \\
\text { knowledge, and } \\
\text { knowledge in certain } \\
\text { engineering } \\
\text { disciplines. }\end{array}$ & $\begin{array}{l}\text { The importance } \\
\text { of training } \\
\text { programs to } \\
\text { improve skills, } \\
\text { minimize } \\
\text { unemployment, } \\
\text { and develop } \\
\text { Malaysia's } \\
\text { workforce. }\end{array}$ \\
\hline $\begin{array}{l}\text { Erabaddag } \\
\text { e Gishan } \\
\text { Tharanga } \\
\text { Sumanasiri, } \\
\text { Mohd } \\
\text { Shukri Ab } \\
\text { Yajid, and } \\
\text { Ali Khatibi } \\
\text { (2015) }\end{array}$ & $\begin{array}{l}\text { Conceptualizing } \\
\text { Learning and } \\
\text { Employability } \\
\text { "Learning and } \\
\text { Employability } \\
\text { Framework". }\end{array}$ & $\begin{array}{l}\text { Propose the new } \\
\text { employability model } \\
\text { of "Learning } \\
\text { framework and } \\
\text { employability". }\end{array}$ & $\begin{array}{l}\text { Imagination/ } \\
\text { Creativity, } \\
\text { Adaptability/ } \\
\text { Flexibility, } \\
\text { Willingness to learn } \\
\text { Independent, } \\
\text { working/autonomy } \\
\text { Working in a team, } \\
\text { Ability to manage } \\
\text { others, } \\
\text { Ability to work under } \\
\text { pressure, } \\
\text { Good oral } \\
\text { communication, } \\
\text { Communication in } \\
\text { writing for varied } \\
\text { purposes/audiences, } \\
\text { Numeracy, } \\
\text { Attention to detail, }\end{array}$ & $\begin{array}{l}\text { Learning and } \\
\text { Employability } \\
\text { are mutually } \\
\text { supportive and } \\
\text { complementary } \\
\text { constructs. }\end{array}$ \\
\hline
\end{tabular}




\begin{tabular}{|c|c|c|c|c|}
\hline & & & $\begin{array}{l}\text { Time management, } \\
\text { Assumption of } \\
\text { responsibility and for } \\
\text { making decisions, } \\
\text { Planning, coordinating } \\
\text { and organizing ability, } \\
\text { Ability to use new } \\
\text { technologies. }\end{array}$ & \\
\hline $\begin{array}{l}\text { Aida et al. } \\
(2015)\end{array}$ & $\begin{array}{l}\text { Critical Success } \\
\text { Factor of } \\
\text { Graduate } \\
\text { Employability } \\
\text { Programs. }\end{array}$ & $\begin{array}{l}\text { Reviewed whether } \\
\text { the content or } \\
\text { context of the } \\
\text { graduates' } \\
\text { employability } \\
\text { program has been } \\
\text { successful in } \\
\text { enhancing the } \\
\text { potential of } \\
\text { graduates } \\
\text { Malaysia. }\end{array}$ & $\begin{array}{l}\text { Reliable, responsible, } \\
\text { problem solving, social } \\
\text { skills, collaboration, } \\
\text { Creativity, negotiating, } \\
\text { action planning and } \\
\text { networking. }\end{array}$ & $\begin{array}{l}\text { Verifying that } \\
\text { graduates' } \\
\text { employability } \\
\text { programs } \\
\text { should } \\
\text { emphasize on } \\
\text { contextual } \\
\text { approaches. }\end{array}$ \\
\hline $\begin{array}{l}\text { Sarimah } \\
\text { Ismail and } \\
\text { Dahiru Sale } \\
\text { Mohamme } \\
\text { d (2015) }\end{array}$ & $\begin{array}{l}\text { Employability } \\
\text { Skills in TVET } \\
\text { Curriculum in } \\
\text { Nigeria Federal } \\
\text { Universities of } \\
\text { Technology. }\end{array}$ & $\begin{array}{l}\text { Discuss how the } \\
\text { curriculum of one of } \\
\text { the TVET programs } \\
\text { at the Federal } \\
\text { Technology } \\
\text { University in Nigeria, } \\
\text { Electrical Education } \\
\text { Technology has } \\
\text { contributed to the } \\
\text { issue of } \\
\text { employability. }\end{array}$ & $\begin{array}{l}\text { Communication Skills, } \\
\text { Technical Writing and } \\
\text { Library Use. }\end{array}$ & $\begin{array}{l}\text { Core skills in the } \\
\text { curriculum do } \\
\text { not have } \\
\text { problem solving } \\
\text { and decision- } \\
\text { making skills, } \\
\text { lifelong learning } \\
\text { skills and } \\
\text { efficiency in } \\
\text { TVET } \\
\text { disciplines. }\end{array}$ \\
\hline $\begin{array}{l}\text { Mohamad } \\
\text { Shukri } \\
\text { Abdul } \\
\text { Hamid, } \\
\text { Rafikul } \\
\text { Islam, and } \\
\text { Hazilah Abd } \\
\text { Manaf } \\
\text { (2014) }\end{array}$ & $\begin{array}{l}\text { Employability } \\
\text { Skills } \\
\text { Development } \\
\text { Approaches: an } \\
\text { Application of } \\
\text { the Analytic } \\
\text { Network } \\
\text { Process. }\end{array}$ & $\begin{array}{l}\text { Evaluate the } \\
\text { importance of } \\
\text { employability skills } \\
\text { and identify the } \\
\text { most effective } \\
\text { development } \\
\text { approaches to } \\
\text { tertiary institutions. }\end{array}$ & $\begin{array}{l}\text { Computing skills, } \\
\text { management skills, } \\
\text { critical thinking skills, } \\
\text { enterprise skills and } \\
\text { entrepreneurial skills, } \\
\text { interpersonal skills, } \\
\text { communication skills } \\
\text { and analytical skills. }\end{array}$ & $\begin{array}{l}\text { The ability to } \\
\text { speak fluently in } \\
\text { English 'is the } \\
\text { most important } \\
\text { skill, followed } \\
\text { by the' ability to } \\
\text { write effectively } \\
\text { in English 'and' } \\
\text { ability to think } \\
\text { critically ' }\end{array}$ \\
\hline $\begin{array}{l}\text { Parmjit } \\
\text { Singh, }\end{array}$ & $\begin{array}{l}\text { Assessing } \\
\text { graduates' }\end{array}$ & $\begin{array}{l}\text { Discussing the issue } \\
\text { of graduates' skills, }\end{array}$ & $\begin{array}{l}\text { Problem Solving Skills, } \\
\text { Critical Thinking Skills, }\end{array}$ & $\begin{array}{l}\text { The model can } \\
\text { generate a lot of }\end{array}$ \\
\hline
\end{tabular}


INTERNATIONAL JOURNAL OF ACADEMIC RESEARCH IN BUSINESS AND SOCIAL SCIENCES Vol. 9, No. 2, Feb, 2019, E-ISSN: $2222-6990$ ๑ 2019 HRMARS

\begin{tabular}{|c|c|c|c|c|}
\hline Thambusa & generic & generic & Interpersonal & research \\
\hline $\begin{array}{l}\text { my, and } \\
\text { Adlan } \\
\text { Ramly } \\
(2014)\end{array}$ & $\begin{array}{l}\text { An indicator of } \\
\text { employability. }\end{array}$ & $\begin{array}{lr}\text { second assessment } \\
\text { in the context of } \\
\text { current } \\
\text { education tertiary } \\
\text { suggesting models } \\
\text { (GEMs) }\end{array}$ & $\begin{array}{l}\text { and Communication } \\
\text { Skills. }\end{array}$ & $\begin{array}{l}\text { terms of its } \\
\text { effectiveness } \\
\text { and } \\
\text { implementation } \\
\text {. }\end{array}$ \\
\hline
\end{tabular}

This article finds that the findings from previous studies have emphasized on employability skills among graduates in line with the real needs and needs of employers. Discussions on past studies also show that employability skills among graduates are a key factor in ensuring employment in the labor market.

\section{Employability skills that Graduates need to master}

Employability skills are an important criterion that can increase the level of employability and marketability of graduates in the labor market (Zaliza \& Arasinah Kami, 2017). The studies conducted by Ridzwan, Ruhizan, and Sattar (2014) have linked the six main constructs of employability skills comprising basic skills, thinking skills, resource skills, interpersonal skills, information technology system skills, quality individual and informational skills to measure the constructs of employability skills that each graduate need to master. Meanwhile, Noor Lela Ahmad and Suraini (2016) have focused on professional skills for graduates. Professionally trained proficiency consists of six skills constructs namely technical skills (accounting, finance and taxation), management skills, information technology skills, intellectual skills, interpersonal skills and personnel skills (Noor \& Suraini, 2016). The Technical and Vocational Education Division (BPTV, 2011) has linked the three key skills to be mastered by every KV graduates. These three key skills have been described in the Vocational Education Skills Dimension which comprise technical skills, entrepreneurial skills and employability skills. This vocational education dimension is a key functional competency for each grader to be produced by KV. In this Vocational Education Dimensional Skill, employability skills are divided into eight skills namely communication, teamwork, problem solving, initiative and entrepreneurship, planning and management, self-management, technology management and learning capabilities. Meanwhile, the implementation of Work Integrated Learning (WIL) and broadened collaborative educational initiatives can enhance professional skills and job readiness; however, graduates often lack the 'employability' (communication, collaboration, problem solving) productivity and innovation at work (McLachlan, \& Lim, 2017).

The most critical skills employability skills available to every graduate in the current global job market required by employers are communication skills, problem solving, teamwork, lifelong learning, entrepreneurship, information management, and leadership skills (Mohamad Shukri Abdul Hamid et al.., 2014). Meanwhile, a study on the effects of graduates' employability skills in Yemen, analytical thinking and problem-solving skills, learning and ongoing management skills, communication skills, entrepreneurial skills, information technology application skills, leadership and management skills, and teamwork and skills interpersonal has been conducted. The study found that 
the listed employability skills are most commonly used in marketing able skills, required by employers, and allow graduates to survive on the market today. The study also expects that these marketable skills will be associated with graduates who are considered marketers (Fatihya, Abdul, \& Norzieiriani, 2017). Meanwhile, Mohd (2015) in his study has identified the most important skills that graduates need to master in obtaining jobs in the competitive labor market as educators, employers, and graduates see. Employability skills are discipline and integrity, interpersonal skills, professionalism, creativity and innovation, lifelong learning, ability to use knowledge, and knowledge in certain engineering fields (Mohd, 2015). All of these studies have emphasized on employability skills for graduates to enable them to gain employment and create their own job opportunities. Previous studies have also found that employability skills are the essential requirements that every graduate need to meet the needs of industry employers.

Alshare (2018) in his study, has identified the 20 dimensions of 'employability' skills for jobs that need to be mastered by Business Management graduates in the 21st century. These skills are critical thinking and problem solving, creativity and innovation, collaboration and teamwork, communication (oral \& written), professionalism, leadership, information technology, interpersonal skills, technical skills, flexibility and suitability, multi-cultural awareness, work ethics, voluntarism, analytical thinking, social responsibility, addressing real world problems, knowledge, creativity / innovation, global business and decision making. Based on the discussion and findings of the previous study, this article has finally been able to formulate six employability skills - analysis and problem solving, communication skills, information technology application skills, leadership and management skills, teamwork and interpersonal skills and entrepreneurial skills as the key skills KV should be focused on the part so that each Business Management graduates master it. Employability skills are emphasized in this study as its role is crucial to improving the degree of employability and marketability of graduates in the labor market. This is also noted in many previous discussions and findings that emphasize the need for skills employability among graduates (Noor \& Suraini, 2016; Pramela et al., 2014; Ridzwan et al., 2014; Suhaili, 2015; Zaliza \& Arasinah, 2017).

\section{Model and Theory of Study}

This article relates Human Capital Theory (Schultz T. W., 1961) which focuses on the needs of the employability skills that must be mastered by each Business Management graduates in KV. Each KV grader needs to have the required employability skills to ensure that they are able to get a job in the labor market and be able to create their own job opportunities. Human Capital Theory is used to assist this article to generate a list of key employability skills needed to improve the degree of workmanship and marketability of KV Business Management graduates in the labor market. The Human Capital Theory introduced by Schultz (1961), has a close relationship to help improve the level of employability and high marketability among graduates. This theory emphasizes on investing in human capital that requires an increase in knowledge and skills education and requires more proactively labor-intensive labor among workers. This theory suggests that qualified workers should be rewarded with the knowledge and skills they possess. However, to make graduates a quality employee, this theory emphasizes that an increase in the comprehensiveness and quality of skills is indispensable. Therefore, graduates with full knowledge and skills are graduates who possess not 
only basic academic skills, but they also need to equip themselves with employability skills. Becker (1975) states that employee productivity can be enhanced by providing education and training through the delivery of relevant skills by any tertiary institution. An increase in employee productivity is expected to increase the future earnings of workers and improve their standard of living. He also pointed out that many employees are able to increase their productivity by learning new skills and completing relevant tasks while working. Workers with extensive skills, especially employability skills, will become more competitive in the labor market. This is because they are considered to be of higher quality and skill that will not only increase their level of employability and marketability but also increase their income.

The Self Concept Theory in Career Development by Super $(1980,1990)$ is also attributed in this article. This theory has often been concentrated by some researchers in recent studies, especially in America and several other countries including in Malaysia itself. Super $(1990,1980)$ in this theory states that career selection and development is a process of developing and implementing one's selfconcept. He also noted that self-concept is the result of complex interactions between several factors involving physical and mental growth, personal experience, mental characteristics and environmental stimuli. The development of vocational skills is a process in building and implementing self-concept. Self-concept is considered more realistic and stable in describing the value of an individual, as well as the choice of vocational skills and desired behaviors. One will choose a job that will enable them to express their own concepts based on what knowledge and skills they have. Their job satisfaction is also related to the level they get in implementing their own self-concept. Super $(1990,1980)$ also found that there were other factors that indirectly influenced the career choice and individual development as well as the self-concept. This is because of the impact of social relationships and individual wins and environmental influences that also affect the career choice and development of an individual. Self-Theory itself is basically the theory that builds on individual personality (Super, 1980, 1990).

The Self-Concept Theory was used in this study to assist Business Management graduates to be more prepared in preparing themselves with the necessary knowledge and skills to enable them to find employment in the labor market and be able to create their own job opportunities. This study emphasizes Self Concept Theory in career development because self-concept is important in determining the career of graduates. Graduates who have a positive self-concept can understand themselves, but they can also accept related things about themselves without making the matter a threat to itself. The involvement of graduates in various development programs that involve relevant skills, can directly build their more self-conceptual concepts. Therefore, this study is confident that positive self-concept can give freedom to graduates to make choices in determining appropriate career. Graduates are also expected to make a decision and are able to cope with all the challenges, but they are also proud of the success they have achieved. In addition, this study relates the Model of Skills Relationships in the study of Sattar, Yusof, Napsiah, Rashid, et al. (2009) based on the report of 'Secretary's Commission on Achieving Necessary Skill' (SCANS, 1991). Three important skills required by employers have been emphasized in this model. These three skills are technical skills, academic basic skills and employability skills. These skills need to be mastered by each grader as a 
neat preparation before stepping into the labor market. This model is an adaptation of the skill set that has been determined by The Secretary's Commission on Achieving Necessary Skills SCANS, (1991).

Based on the model, theories and previous studies that have been discussed, this article is finally able to produce a theoretical framework of the study that can link six employability skill. These are analysis and problem solving, communication skills, information technology application skills, leadership and management skills, work teamwork and interpersonal skills and entrepreneurial skills with the workmanship and marketability of graduates. This theory framework can be shown in Figure 3.1:

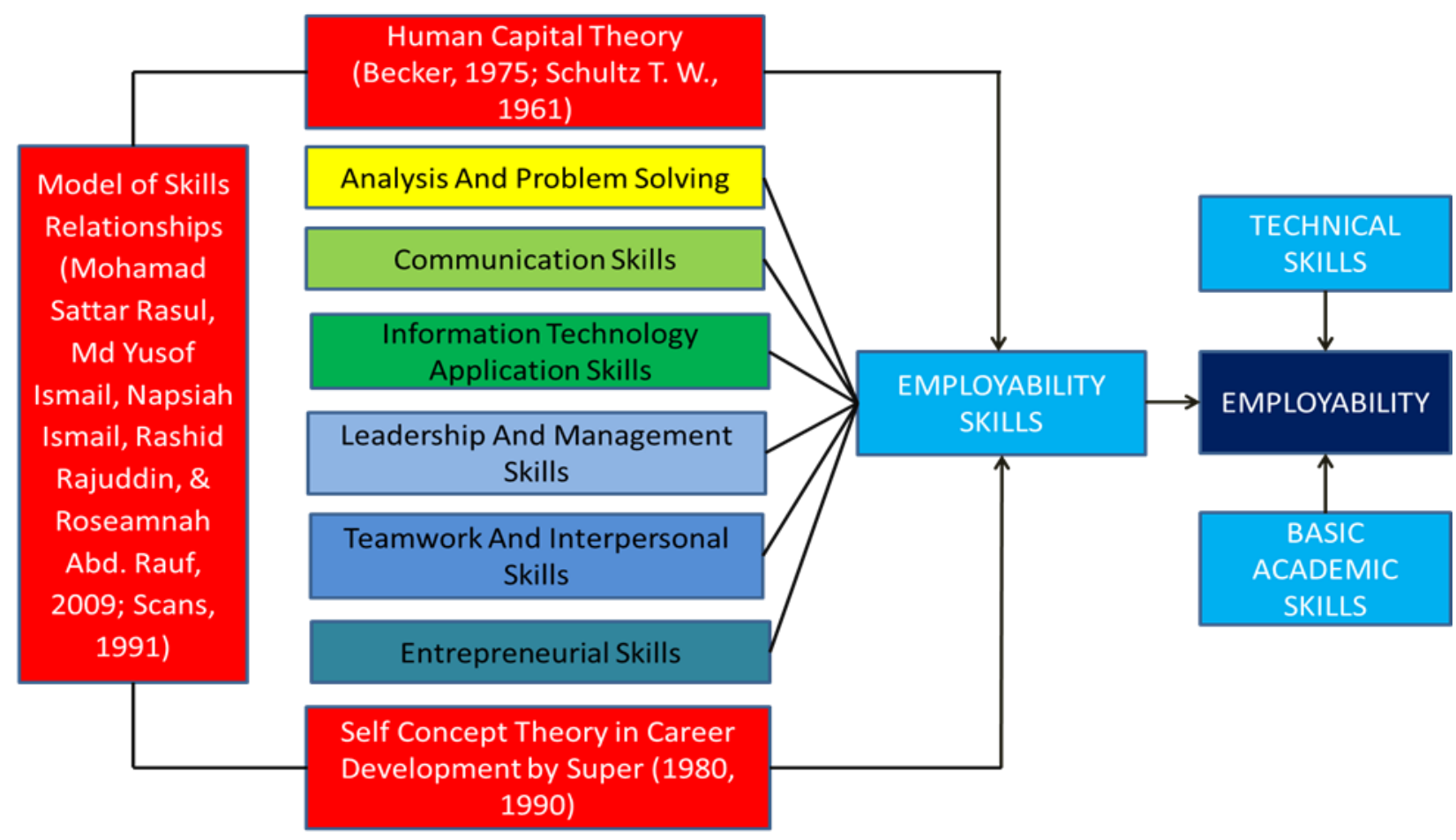

Figure 1. Graduates' Employability Skills Theoretical Framework

(Becker, 1975; Schultz T. W., 1961; Super, 1980; Super, 1990; Mohamad Sattar Rasul, Md Yusof Ismail, Napsiah, Rashid, et al., 2009; SCANS, 1991).

The Role of Vocational Colleges to Foster the Employability Skills Among Business Management Graduates

Enhancing graduates' marketability is a priority for many stakeholders in tertiary education (O'Leary, 2017). The responsibility of tertiary institutions in the development of employability skills for business management graduates to improve performance at work is undisputed. This includes the role of KV in producing highly skilled Business Management graduates according to current needs. The KV party 
needs to identify several ways to tailor the appropriate curriculum and pedagogy to improve the skills of graduates (Jackson, 2016a). Other factors such as geographic origin, sex, work experience, involvement with skills agendas, degree studies, relationship scope and outdoors of education and employment as well as the quality of skills development in program learning can influence the skills of 'employability' (Jackson, 2016a). The study conducted by Jackson (2016) also supported the findings of many previous studies which emphasized the need for mastering skills of employability among graduates. The employer considers that the ability to master the employability skills is still the responsibility of tertiary institutions and has a great role to explain exactly the skills required by business graduates (Bishanani et al., 2016).

Meanwhile, Mohd (2015) study found that educators and graduates agreed on the positive impact of training programs on the skills of the trainers. However, employers are of the view that the job skills training program is insufficient to ensure skill upgrades, reduce unemployment, or expand the workforce. Therefore, $\mathrm{KV}$ is advised to plan and implement more effective and quality training programs in order to inculcate employability skills among Business Management graduates in line with the wishes of the industry employers. The KV also needs to identify a number of other factors that are expected to affect the improvement in graduates' employability skills and facilitate their involvement in training programs (Mohd, 2015). Implementation of the work-integrated learning practices by the KV, through job assignments, can help graduates to improve their employability skills. There is evidence to demonstrate the need to systematically assess the skills, competencies and behaviors of graduates for development purposes as well as support for continuous feedback and critical reflection on graduates' progress towards development goals, but also recognize the importance of graduates to practice the orientation of learning goals to maximize benefits their experience (McLachlan et al., 2017). Therefore, industry involvement in innovative joint ventures is needed to achieve the equivalent training form of industrial demand and thus generate a smoother transition of graduates from institutions to work (Boahin, 2018).

The study of graduates' skills should be carried out by the KV so that it can identify the shortcomings and needs that need to be improved and subsequently carry out curriculum reviews and changes according to the needs in business management education. For Business Management graduates who are graduating, employability skills education should be included in the KV curriculum. This is intended to produce complete graduates with the skills required for employment in the local and international labor market (Bishanani et al., 2016). Therefore, the focus should be on employability skills where educators should teach relevant skills according to the employer's needs (Bishanani et al., 2016). The KV also needs to give a balanced emphasis on both technical skills and employability in its curriculum through integration to produce competent and competitive workers (Zaliza \& Arasinah, 2017). Transition of tertiary institutions from higher order skills, intellectual intelligence and core skill leadership in a given field of expertise and vocational skills are both necessary and challenging, yet employability skills remain a priority and thus affect the curriculum policy and reforms in institutions tertiari especially in KV (Jackson, 2016b). KV parties need to focus on employability skills as well as certain skills that are specific to Business Management graduates such as management and accounting skills. 
The use of relevant technology in the teaching and learning process is important. According to Nur Farha Hassan et al. (2018), there are five elements of TEAL approaches required in the Technical and Vocational Education and Training (TVET) institutions, Elements of online learning, Elements of Blended Learning, Elements of Collaborative Learning, Elements of Practical Learning and Elements of Interactive Learning graduates' employability skills. These elements are important for classroom use to ensure that each student is able to participate in an active environment to develop learning experiences. The combination of these elements will help graduates improve their knowledge, skills and experience in technical work by using technology innovation tools (Nur Farha Hassan et al., 2018). These five elements need to be applied in the process of learning in KV and should be practiced by every graduate to gain employment in the labor market as these elements are among the key prerequisites to be a measure of their skills and skills when they work.

In addition, the quality of knowledge and skills among KV teachers should be addressed. This is to ensure that the teaching process can be implemented more effectively where instructors should link skills taught in the work environment in each of their teaching sessions (Bishanani Omar et al., 2016). Teachers need to teach the students the skills they want employers. This can be done by establishing links between KV and industry employers and involving them in designing the curriculum. Therefore, the industry will actively participate in influencing the business curriculum according to the required skills requirement. Additionally, this collaboration will influence business instructors to change and update business curriculum equivalent to the employer's needs (Alshare, 2018). KV parties are also advised to emphasize 12 main domains for the purpose of establishing the competence of graduates' behavior and skills, namely governance, eligibility framework, competency standards, skills standard suppliers, delivery, industrial relations, industrial work experience, twinning programs, service programs community, curriculum-based industrial visits, and entrepreneurship education (Noorazman Abd Samad et al., 2018). The responsibility to improve employability skills among graduates is considered as an important task not only in KV but also for tertiary institutions in Malaysia and abroad (Aida et al., 2015). It is also the responsibility of all stakeholders to develop the awareness and explicit relationships among graduates with the process of identity creation (Jackson, 2016b).

\section{Conclusion}

Labor market is now a place for graduates of tertiary institutions to compete for employment. This situation will determine the fate of their lives in the future. It is also a measure of the capabilities and achievements of tertiary institutions in producing graduates of either quality or otherwise. This clarifies that the need for skills employability is essential to be mastered by each KV grader in particular, to enable them to compete for employment in the current labor market. Therefore, the employability skills highlighted in this article are important to assist related parties especially KV to prepare Business Management graduates with the level of employability and desired marketability so that they can not only gain employment in the labor market, but they are also capable of creating opportunities own job. The need for six employability skills - analytical thinking and problem solving skills, communication skills, information technology application skills, leadership and management skills, teamwork skills and interpersonal skills, and entrepreneurial skills - are the main 'employability' 
INTERNATIONAL JOURNAL OF ACADEMIC RESEARCH IN BUSINESS AND SOCIAL SCIENCES

Vol. 9, No. 2, Feb, 2019, E-ISSN: 2222-6990 C 2019 HRMARS

skills to be given special attention by KV so that every Business Management graduates have marketable skills in the labor market in line with the needs and requirements of the industry employers. Graduates with these employability skills have the advantage of getting jobs with any organization and can be adapted to any occupational or employment situation (Aida et al., 2015).

\section{Acknowledgement}

Thank you to all who have helped the author in preparing this article paper. Thank you to Dr. Arasinah binti Kamis on cooperation, guidance and motivation guide. Thanks also to all lecturers of the Business Management Program, vocational colleges and the Technical and Vocational Education Division (BPTV) on the data and information retrieval of vocational colleges. Hopefully the writing of this article paper will benefit all parties.

\section{Corresponding Author}

Arasinah binti kamis

Faculty of Technical and Vocational,

Sultan Idris Education University (UPSI)

35900 Tanjung Malim, Perak,

Malaysia.

Email: arasinah@ftv.upsi.edu.my

\section{References}

Alshare, K. (2018). A Gap Analysis Of Business Students' Skills In The 21 St Century: A Case Study Of Qatar. Academy of Educational Leadership Journal (Vol. 22). Retrieved from https://www.abacademies.org/articles/A-gap-analysis-of-business-students-skills-in-the-21Stcentury-a-case-study-1528-2643-22-1-110.pdf

Atif, A., \& Faizuniah, P. (2017). Moderating Effect of Emotional Intelligence on the Relationship between Personality Traits and Employability. Saudi Journal of Humanities and Social Sciences, 2(2), 132-139. https://doi.org/10.21276/sjhss.2017.2.2.4

Technical and Vocational Education Division,, https://www.moe.gov.my/index.php/my/korporat/jabatan-dan-bahagian/bahagianpendidikan-teknik-dan-vokasional

Becker, G. (1975). Human Capital: A Theoretical and Empirical Analysis, with Special Reference to Education. National Bureau of Economic Research (Vol. 2). https://doi.org/10.1007/978-184882-587-1_8

Omar, B., Zamri, S. N. A. S., \& Alias, N. (2016). Kemahiran Kebolehpekerjaan : Isu Graduan Pengurusan Perniagaan Kolej Vokasional. ResearchGate. Retrieved from https://www.researchgate.net/publication/313517099\%0AKemahiran

Boahin, P. (2018). Competency-Based Curriculum: A Framework For Bridging The Gap In Teaching, Assessment And The World Of Work. International Journal of Vocational and Technical Education Research (Vol. 4). Retrieved from www.eajournals.org

Chun, M. C., \& Chien, H. S. (2015). Tertiary Students' Entrepreneurship Learning Socialization : Factor 
INTERNATIONAL JOURNAL OF ACADEMIC RESEARCH IN BUSINESS AND SOCIAL SCIENCES

Vol. 9, No. 2, Feb, 2019, E-ISSN: $2222-6990$ ๑ 2019 HRMARS

Analysis and Structural Equation Modeling, 2(3), 32-38.

Erabaddage Gishan Tharanga Sumanasiri, Mohd Shukri Ab Yajid, \& Ali Khatibi. (2015). Conceptualizing Learning and Employability "Learning and Employability Framework." Journal of Education and Learning, 4(2), 53-63. https://doi.org/10.5539/jel.v4n2p53

Malaysia Department of Statistics (2018). https://www.dosm.gov.my/v1/index.php?r=column/pdfPrev\&id=VzBiQIBKSVc0SOhRN0x1RDBq R09BZz09. Dilayari pada 15 Februari 2018.

Jackson, D. (2013). Business graduate employability - where are we going wrong? Higher Education Research and Development, 32(5), 776-790. https://doi.org/10.1080/07294360.2012.709832

Jackson, D. (2016a). Modelling graduate skill transfer from university to the workplace. Journal of Education and Work, 29(2), 199-231. https://doi.org/10.1080/13639080.2014.907486

Jackson, D. (2016b). Re-conceptualising graduate employability: the importance of pre-professional identity. Higher Education Research and Development, 35(5), 925-939. https://doi.org/10.1080/07294360.2016.1139551

Jackson, D., \& Chapman, E. (2012). Non-technical skill gaps in Australian business graduates NonTechnical Skill Gaps In Business Graduates. Edith Cowan University Research Online, 54(2-3), 95113. https://doi.org/10.1108/00400911211210224

Kee-Cheok Cheong, Hill, C., Fernandez-Chung, R., \& Yin-Ching Leong. (2016). Employing the "unemployable": employer perceptions of Malaysian graduates. Studies in Higher Education, 41(12), 2253-2270. https://doi.org/10.1080/03075079.2015.1034260

Mane, F., \& Miravet, D. (2016). Using the job requirements approach and matched employeremployee data to investigate the content of individuals' human capital. Journal for Labour Market Research, 49(2), 133-155. https://doi.org/10.1007/s12651-016-0203-3

McLachlan, K., Yeomans, L., \& Lim, K. Z. G. (2017). A competency development approach to learning for employment (pp. 793-800). https://doi.org/10.4995/HEAD17.2017.5421

O'Leary, S. (2017). Graduates' experiences of, and attitudes towards, the inclusion of employabilityrelated support in undergraduate degree programmes; trends and variations by subject discipline and gender. Journal of Education and Work, 30(1), 84-105. https://doi.org/10.1080/13639080.2015.1122181

Schultz T. W. (1961). Investment in Human Capital. The American Economic Review, 51(1), 1-17. https://doi.org/10.1007/sl0649-007-9105-I

Suhaili Hanafi. (2015). Kesediaan Pelajar Dari Aspek Kemahiran Teknikal Terhadap Pembentukan Kebolehkerjaan Di Kolej Vokasional Wilayah Selatan. Uneversiti Tun Hussein Onn. Retrieved from http://eprints.uthm.edu.my/7117/1/SUHAILI_BINTI_HANAFI_24.pdf

Super, D. E. (1980). A life-span, life-space approach to career development. Journal of Vocational Behavior, 16(3), 282-298. https://doi.org/10.1016/0001-8791(80)90056-1

Super, D. E. (1990). A life-span, life space approach to career development. In Career Choice and Development (2nd ed) (pp. 197-261).

United Nations General Assembly. (2015). Transforming our world: The 2030 agenda for sustainable development.

https://sustainabledevelopment.un.org/content/documents/7891Transforming\%200ur\%20Wo rld. pdf. https://doi.org/10.1007/s13398-014-0173-7.2 
Williams, S., Dodd, L. J., Steele, C., \& Randall, R. (2016). A systematic review of current understandings of employability. Journal of Education and Work, 29(8), 877-901. https://doi.org/10.1080/13639080.2015.1102210

Windes, D. L., \& Hamilton, R. A. (2017). Preparing Business Students for Participation in God â€ $€^{\mathrm{TM}} \mathrm{S}$ Creative and Redemptive Purpose for the World Preparing Business Students for Participation in God 's Creative and Redemptive Purpose for the World. Spring, (June), 149-160. Retrieved from https://www.researchgate.net/publication/317689843 